практиці та зміст діяльності викладача, спрямованої на підготовку та організацію навчання з урахуванням МЗ. Доробок науковців-дидактів був основою під час розроблення методики застосування МЗ курсів «Загальної фізики» та «Основи охорони праці» в процесі підготовки майбутніх учителів, яку буде викладено в подальших публікаціях.

\title{
Література
}

1. Антонов Н. С. Слагаемые знаний: о межпредметных связях в учебном процессе / Н. С. Антонов. - Архангельск : Сев-Зап. кн. изд-во, 1969. - 152 с.

2. Бібік Г. В. Міжпредметні зв'язки математики і фізики як засіб формування ключових компетентностей учнів основної школи : автореф. дис. на здобуття наук. ступеня канд. пед. наук : спец. 13.00 .02 «Теорія та методика навчання (математика)»/ Г. В. Бібік. - Херсон, 2010. - 20 с.

3. Гончаренко С. У. Зміст освіти і їі гуманітаризації / С. У. Гончаренко; за ред. І. Я. Зязюна. - К., 2000. - 161 с.

4. Зверев И. Д. Взаимная связь учебных предметов / И. Д. Зверев. - М. : Знание, 1977. $-126 \mathrm{c}$

5. Ильина Т. А. Педагогика / Т. А. Ильина. - М. : МГПИ, 1977. - 258 с.

6. Калягин Ю. М. Интеграция школьного обучения / Ю. М. Калягин, О. Л. Алексенко // Начальная школа. - 1990. - № 9. - С. 28-29.

7. Касперський А. В. Радіоелектроніка в системі формування фізичних і технічних знань у середніх загальноосвітніх та вищих педагогічних навчальних закладах: дис. ... докт. пед наук : 13.00.02 / Касперський Анатолій Володимирович. - К., 2003. - 524 с.

8. Козловська I. М. Теоретико-методологічні аспекти інтеграції знань учнів професійно-технічної школи: дидактичні основи / І. М. Козловська.- Львів, 1999. - 302 с.

Стаття надійшла до редакції 14.05.2012 p.

\section{ТЕХНОЛОГІЯ ФОРМУВАННЯ ВМІНЬ КОНСТРУКТИВНОЇ ВЗАЕМОДІЇ МАЙБУТНІХ МЕНЕДЖЕРІВ} менеджерів.

Гагіна Н. В. Технологія формування вмінь конструктивної взаємодї майбутніх

У статті подано технологію формування в майбутніх менеджерів умінь конструктивної взаємодії в ситуачії конфлікту, визначено ї̈ компоненти. Формування вмінь конструктивної взаємодї здійснюється відповідно до таких етапів: діагностувально-мотивачійного, теоретичного, тренувально-діяльнісного, рефлексивно-коригувального та творчого.

Ключові слова: педагогічна технологія, формування вмінь конструктивної взаємодії в ситуації конфлікту, майбутні менеджери.

Гагина Н. В. Технология формирования умений конструктивного взаимодействия будущих менеджеров.

В статье представлена технология формирования у будущих менеджеров умений конструктивного взаимодействия в ситуации конфликта, определень ее компоненты. Формирование умений конструктивного взаимодействия осуществляется в соответствии со следующими этапами: диагностико-мотивационного, теоретического, тренировочнодеятельностного, рефлексивно-корректирующего и творческого.

Ключевые слова: педагогическая технология, формирование умений конструктивного взаимодействия в ситуации конфликта, будущиие менеджеры. 
Hahina N. The technology of formation of would-be managers' constructive interaction skills.

The technology of formation of would-be managers' skills of constructive interaction in a conflict situation is introduced in the article. The technology components are determined. The formation of constructive interactionskills is carried out in accordance with the followings stages: diagnosticmotivational, theoretical, training, reflection-correctional and creative.

Key words: educational technology, formation of skills of constructive interaction in a conflict situation, would-be managers.

Постановка проблеми. Актуальність підготовки майбутніх менеджерів до конструктивної взаємодії в ситуації конфлікту зумовлена соціальним запитом на висококваліфікованих i компетентних фахівців, здатних продуктивно діяти в складних, часто стресогенних умовах професійної діяльності, гнучко реагувати на швидкоплинні процеси змін та інновацій. Формування вмінь конструктивної взаємодії $\epsilon$ важливим чинником підвищення професіоналізму, соціальної культури майбутнього менеджера та підгрунтям самоактуалізації й самореалізації особистості.

У межах окресленої проблематики вдосконалення професійної підготовки майбутніх фахівців 3 менеджменту потребує розроблення спеціальної технології навчання для оволодіння практичним досвідом конструктивного розв'язання конфліктів у професійній та особистісній сферах.

Концептуальні засади педагогічної технології розкрито в працях В. Беспалька, М. Кларіна, А. Нісімчука, О. Падалки, О. Пєхоти, Г. Селевка, С. Сисоєвої, В. Сластьоніна та інших, використанню технологічного підходу до підготовки майбутніх фахівців присвячено роботи В. Береки, С. М. Бойко, С. Вітвіцької, Л. Волкової, Л. Воротняк, В. Сремеєвої, С. Карплюк, Ю. Костюшка, В. Матвійчука, О. Мисечко, О. Романишиної, І. Романюка, А. Рибачук, Н. Щерби та інших.

Проте на нинішньому етапі розвитку теорії і практики професійної освіти бракує наукових досліджень, практичних розробок, які б пропонували ефективні технології навчання майбутніх менеджерів конструктивному розв'язанню конфліктів.

Мета статті - науково обгрунтувати й описати технологію формування в майбутніх менеджерів умінь конструктивної взаємодії в ситуації конфлікту.

Вибір технологічного підходу до формування вищезазначених умінь зумовлений тим, що, на відміну від традиційного навчання, педагогічна технологія дозволяє побудувати i здійснити навчальний процес, який гарантує досягнення визначених цілей. Запланований результат педагогічної діяльності досягається завдяки послідовній орієнтації навчання на визначені цілі, що стає можливим завдяки зворотному зв'язку, який здійснюється протягом всього навчального процесу. Ознаками педагогічної технології $\epsilon$ визначення й уточнення цілей навчання, орієнтація процесу навчання на чітко визначені цілі, спрямованість цілей і всього навчального процесу на досягнення конкретного результату, оцінювання поточних результатів, корекція навчання, заключне оцінювання результатів [1]. 
В обгрунтуванні технології формування вмінь конструктивної взаємодії, необхідних майбутнім менеджерам для ефективного розв'язання конфлікту, спираємося на наукові погляди I. Лернера, який уважає, що структура змісту освіти має бути ізоморфною структурі змісту соціального досвіду, який складається 3 чотирьох елементів - знання про способи діяльності, досвід виконання діяльності, досвід творчої діяльності та емоційно-чуттєвий досвід [2].

Найчастіше в процесі навчання основна увага приділяється першим двом елементам. Як засвідчує практика, третій елемент є надзвичайно важливим у формуванні вмінь конструктивної взаємодії, оскільки саме досвід творчої діяльності забезпечує можливість вирішувати не тільки повторюваних, а й незнайомих завдань у нових умовах, комбінуючи відомі способи розв'язання проблеми та створюючи нові.

Погоджуємося $з$ думкою І. Лернера стосовно того, що основна функція проблемного продуктивного навчання полягає в отриманні досвіду творчої діяльності, а для засвоєння знань, навичок та вмінь найбільш ефективним $\epsilon$ репродуктивне навчання, оскільки абсолютно недоцільним виявляється організація навчання, за якої доведеться знову відкривати те, що раніше було відкрите людством. Значна частина способів діяльності формується i закріплюється вправами на репродуктивному етапі й тільки певна частина знань та вмінь, яка здобувається самостійно в процесі проблемного навчання, дозволяє сформувати особливі структури мислення [3, с. 51-52].

3 огляду на зазначене вище вважаємо, що процес формування професійних умінь має складатися з ефективної комбінації репродуктивного i продуктивного навчання, спеціально підібраної з урахуванням специфіки майбутньої діяльності фахівця.

Розглядаючи питання продуктивного і репродуктивного навчання в контексті нашого дослідження, варто зазначити, що перш, ніж розпочинати процес формування вмінь, потрібно визначити необхідний рівень їх засвоєння, який буде достатнім для здійснення діяльності. Окремі вміння конструктивної взаємодії (уміння самоконтролю, безоцінного сприйняття, активного слухання, аргументації тощо) необхідно сформувати на репродуктивному етапі за допомогою вправ, проте, реалізація комплексу вмінь конструктивної взаємодії в ситуації конфлікту, до якого ми відносимо організаторські, аналітичні, комунікативні, рефлексивні, регулятивні, проектувальні вміння, $є$ за своєю суттю творчим моментом, оскільки процес розв'язання конфлікту не підлягає стереотипізації. Ні грунтовні знання, ні вміння, засвоєні за зразком, не забезпечать оволодіння творчим досвідом діяльності. Отже, для формування вмінь конструктивної взаємодії в ситуації конфлікту необхідно створити умови реального пошуку розв'язання проблеми, що можливо тільки під час продуктивного навчання.

Визначаючи вміння як особистісне утворення, яке означає здатність людини ефективно і якісно виконувати діяльність, вважаємо, що в процесі засвоєння вмінь відбувається не тільки оволодіння досвідом виконання діяльності, а й формування світогляду, переконань, ціннісних орієнтацій, що 
детермінують цю діяльність. Отже, четвертий компонент у структурі соціального досвіду $є$ необхідним складником освіти і важливим компонентом процесу вироблення професійних умінь. А формування вмінь конструктивної взаємодії в ситуації конфлікту $\epsilon$ цілеспрямованим процесом навчання способам діяльності з розв'язання конфлікту, в результаті якого відбувається виникнення стійких форм поведінки, утворення ціннісних орієнтацій та особистісних якостей, що сприяють реалізації конструктивної взаємодії в ситуації конфлікту.

Розроблена технологія формування в майбутніх менеджерів умінь конструктивної взаємодії в ситуації конфлікту, що містить цільовий, змістовий, організаційно-процесуальний та оцінно-результативний компоненти, (див. рис. 1) грунтується на ключових вимогах до технологізації навчання, основних положеннях теорії діяльності, дидактичних принципах побудови навчально-виховного процесу, концепції поетапного формування вмінь і системі засвоєння соціального досвіду.

Цільовий компонент окреслює головну мету педагогічної діяльності формування вмінь майбутніх менеджерів конструктивної взаємодії в ситуації конфлікту, зумовлену соціальним замовленням суспільства, та індивідуальними потребами майбутніх фахівців 3 менеджменту в самовдосконаленні професійної та особистісної життєдіяльності на засадах толерантності та конкретні цілі навчання, зорієнтовані на досягнення очікуваного результату.

3-поміж основних навчальних цілей виокремлюємо такі:

- знати, розуміти, тлумачити поняття: конфлікт, ознаки конфліктів, типи конфліктів, внутрішньо-особистісні конфлікти, міжособистісні конфлікти, конфлікт між особистістю та групою, міжгрупові конфлікти, структура конфлікту, динаміка конфлікту, типи завершення конфліктів, стратегія реагування на конфлікт, чинники визначення ситуації як конфліктної, конфліктна взаємодія, конструктивна взаємодія в ситуації конфлікту, стратегія і тактика конструктивної взаємодії в ситуації конфлікту, управління конфліктом, технологія розв'язання міжособистісного конфлікту, аналіз ситуації конфлікту, міжособистісні бар'єри комунікації під час конфліктної взаємодії;

- уміти встановлювати та налагоджувати контакт, застосовувати техніки саморегуляції, активного слухання, вести діалог, аргументувати думку та переконувати опонента, долати міжособистісні бар'єри комунікації, аналізувати ситуацію конфлікту, проектувати та організовувати конструктивну взаємодію в ситуації конфлікту, обирати доцільні способи розв'язання конфлікту, виробляти механізми співпраці, реалізовувати стратегію співробітництва під час розв'язання конфлікту тощо.

Змістовий компонент спрямований на вдосконалення змісту конфліктологічної підготовки майбутніх менеджерів. Значна затеоретизованість навчального процесу, домінування лекційних і семінарських занять та використання традиційних методів навчання не дозволяють здійснити якісну підготовку майбутніх фахівців з менеджменту до конструктивного розв'язання конфліктів у міжособистісній та професійній сфері, не сприяють становленню особистості фахівця, спроможного до професійної самореалізації в стресовому, конфліктогенному середовищі. 


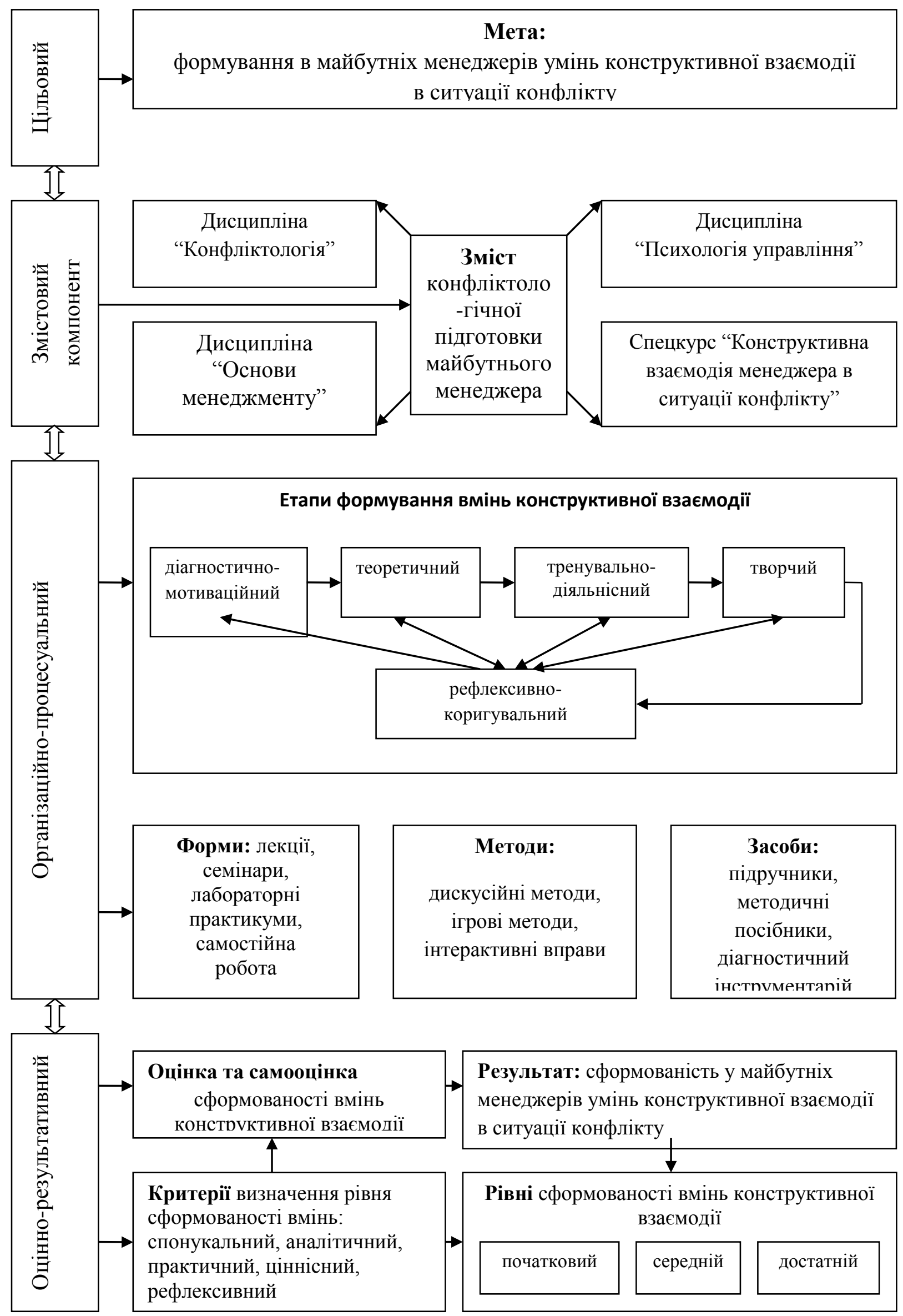

Рис. 1. Технологія формування в майбутніх менеджерів умінь конструктивної взаємодії в ситуачії конфлікту 
Отже, для підсилення практичної складової підготовки майбутніх менеджерів до реалізації конструктивної взаємодії в ситуації конфлікту, необхідно ввести значну кількість годин лабораторних практикумів.

Організаційно-проиесуальний компонент, що складається 3 діагностувально-мотиваційного, теоретичного, тренувально-діяльнісного, рефлексивно-коригувального та творчого етапів, орієнтований на організацію й реалізацію процесу поетапного формування вмінь конструктивної взаємодії майбутніх менеджерів у ситуації конфлікту.

Навчання студентів конструктивній взаємодії в ситуації конфлікту ускладнене тим, що в процесі життєдіяльності в них уже сформувався той чи той домінуючий тип взаємодії (поведінки), який найчастіше обирається в ситуації конфлікту. За даними опитувань майбутніх менеджерів найбільший відсоток мають такі стратегії взаємодії в конфлікті, як ухиляння - 37\%, боротьба - 30\%, компроміс - 26\%, стратегію співробітництва обирає дуже невеликий відсоток опитуваних - 7\%. Тому метою діагностувальномотиваційного етапу $\epsilon$ самодіагностування й визначення студентами наявних у них орієнтацій і типу домінуючої взаємодії за допомогою методик самооцінки, створення мотивації їх змін і корекції, усвідомлення необхідності формування, розвитку та вдосконалення вмінь конструктивної взаємодії в ситуації конфлікту.

Кооперативний контекст навчальної взаємодії, використання сучасних інтерактивних методів, діалогічне навчально-виховне середовище, фасилітація та підтримка викладача забезпечують виникнення стійкої мотивації формування вмінь конструктивної взаємодії, спонукають до самонавчання, самовиховання, саморозвитку, сприяють усвідомленню майбутніми менеджерами важливості конструктивної міжособистісної взаємодії, толерантного і компромісного мислення під час розв'язання конфлікту.

Уміння конструктивної взаємодії грунтуються на знаннях про конфлікт як закономірний соціальний феномен, його причини, стадії розвитку, чинники та умови, що впливають на вибір стратегії поведінки, психічні процеси, правила поведінки, методи саморегуляції та переконливого впливу в конфліктній ситуації тощо.

Наступний теоретичний етап спрямований на актуалізацію знань та поглиблення теоретичної бази підготовки майбутніх менеджерів до конструктивної взаємодії в ситуації конфлікту передбачає не тільки репродуктивне відтворення знань, отриманих на лекціях та практичних заняттях, а й відбір необхідного для формування вмінь теоретичного матеріалу, встановлення зв'язків між накопиченими знаннями та їх практичним застосуванням.

Метою тренувально-діяльнісного етапу $є$ формування за допомогою різноманітних інтерактивних вправ, дискусійних та ігрових методів окремих умінь і навичок здійснення конструктивної взаємодії в ситуації конфлікту, синтез набутих умінь, їх комплексне застосування в ситуації взаємодії на прикладах розв’язання конфліктів, у тому числі, що виникають в умовах 
професійної діяльності. На цій стадії вміння формуються в неконфліктному контексті, в атмосфері захищеності, психологічного комфорту та підтримки, враховуючи індивідуальні особливості студентів; здійснюється постійний контроль за правильністю виконання поставленого завдання; відбувається заохочення студентів до саморефлексії, визначення труднощів у процесі навчання; використовується кооперативна та діалогічна взаємодія для їх подолання. Для формування комплексу вмінь застосовуються переважно ділові та рольові ігри, в яких моделюються складні ситуації міжособистісної та професійної взаємодії.

Творчий етап передбачає самовдосконалення набутих умінь, використання творчого підходу до розв'язання конфліктів не тільки в навчальному середовищі, а й в реальних ситуаціях соціальної взаємодії, усвідомлення особистісних змін на основі глибокої рефлексії.

Рефлексивно-коригувальний етап спрямований на здійснення корекції навчання на основі рефлексії, зворотного зв'язку, оцінки викладача та самооцінки задля вдосконалення процесу формування вмінь конструктивної взаємодії в ситуації конфлікту.

Виховання емоційної культури, розвиток системи цінностей та індивідуальних якостей, що складає четвертий елемент засвоєння соціального досвіду, відбувається впродовж всього навчального процесу відповідно до змісту освіти й забезпечується обраними методами, формами роботи та педагогічними умовами на кожному рівні підготовки до реалізації конструктивної взаємодії майбутніх менеджерів у ситуації конфлікту.

Оиінно-результативний компонент технології передбачає оцінку та самооцінку вмінь конструктивної взаємодії майбутніх менеджерів у ситуації конфлікту та визначення рівня їх сформованості.

Отже, реалізація технології формування в майбутніх менеджерів умінь конструктивної взаємодії в ситуації конфлікту дозволяє побудувати цілеспрямований і ефективний процес навчання, що забезпечить досягнення очікуваного результату педагогічної діяльності - сформованості в майбутніх менеджерів умінь, необхідних для конструктивного розв'язання проблем міжособистісної взаємодії в професійній сфері.

\section{Література}

1. Кларин М. В. Педагогическая технология в учебном процессе. Анализ зарубежного опыта / Михаил Владимирович Кларин. - М. : Знание, 1989. - 80 с. (Педагогика и психология ; № 6).

2. Лернер И. Я. Дидактические основы методов обучения / Исаак Яковлевич Лернер. - М. : Педагогика, 1981. - 186 с.

3. Лернер И. Я. Проблемное обучение / Исаак Яковлевич Лернер. - М. : Знание, 1974. $-64 \mathrm{c}$.

Стаття надійшла до редакції 11.05.2012 p. 